\title{
Endophytic bacterial diversity in the phyllosphere of Amazon Paullinia cupana associated with asymptomatic and symptomatic anthracnose
}

\author{
Andréa Cristina Bogas ${ }^{*}$, Almir José Ferreira², Welington Luiz Araújo², Spartaco Astolfi-Filho3, \\ Elliot Watanabe Kitajima ${ }^{4}$, Paulo Teixeira Lacava ${ }^{5}$ and João Lúcio Azevedo ${ }^{1}$
}

\begin{abstract}
Endophytes colonize an ecological niche similar to that of phytopathogens, which make them candidate for disease suppression. Anthracnose is a disease caused by Colletotrichum spp., a phytopathogen that can infect guarana (Paullinia cupana), an important commercial crop in the Brazilian Amazon. We investigated the diversity of endophytic bacteria inhabiting the phyllosphere of asymptomatic and symptomatic anthracnose guarana plants. The PCR-denaturation gradient gel electrophoresis (PCR-DGGE) fingerprints revealed differences in the structure of the evaluated communities. Detailed analysis of endophytic bacteria composition using culture-dependent and 16S rRNA clone libraries revealed the presence of Firmicutes, Proteobacteria, Actinobacteria, Bacteroidetes, and Acidobacteria phyla. Firmicutes comprised the majority of isolates in asymptomatic plants $\left(2.40 \mathrm{E}^{-4}\right)$. However, cloning and sequencing of $16 \mathrm{~S}$ rRNA revealed differences at the genus level for Neisseria $\left(1.4 \mathrm{E}^{-4}\right)$, Haemophilus $\left(2.1 \mathrm{E}^{-3}\right)$ and Arsenophonus $\left(3.6 \mathrm{E}^{-5}\right)$ in asymptomatic plants, Aquicella $\left(3.5 \mathrm{E}^{-3}\right)$ in symptomatic anthracnose plants, and Pseudomonas $\left(1.1 \mathrm{E}^{-3}\right)$, which was mainly identified in asymptomatic plants. In cross-comparisons of the endophytic bacterial communities as a whole, symptomatic anthracnose plants contained higher diversity, as reflected in the Shannon-Weaver and Simpson indices estimation $(P<0.05)$. Similarly, comparisons using LIBSHUFF and heatmap analysis for the relative abundance of operational taxonomic units (OTUs) showed differences between endophytic bacterial communities. These data are in agreement with the NMSD and ANOSIM analysis of DGGE profiles. Our results suggest that anthracnose can restructure endophytic bacterial communities by selecting certain strains in the phyllosphere of P. cupana. The understanding of these interactions is important for the development of strategies of biocontrol for Colletotrichum.
\end{abstract}

Keywords: Colletotrichum, Culture dependent, Endophytes, PCR-DGGE, Clone library, Microbial diversity

\section{Background}

Globally, Brazil is the unique commercial-scale producers of guarana [Paullinia cupana var. sorbilis (Mart.) Ducke]. It is estimated that at least $70 \%$ of the national market is intended for the manufacture of soft drinks, while the remainder is marketed in the forms of syrup, stick, powder, extract and other products (Bentes and

\footnotetext{
*Correspondence: andreabogas@hotmail.com

1 Department of Genetics, "Luiz de Queiroz" College of Agriculture, University of São Paulo, Av. Pádua Dias 11, PO BOX 83, Piracicaba, SP 13400-970, Brazil

Full list of author information is available at the end of the article
}

Costa Neto 2011). Furthermore, the derivatives from guarana are economically valuable resources throughout the pharmaceutical and cosmetics industries (Kuri 2008) and are widespread in the global market. A study of the guarana fruits transcriptome performed by Ângelo et al. (2008) revealed the presence of secondary metabolites in this plant, such as flavonoids, which are powerful antioxidants, and the common stimulant caffeine; this study permitted a better elucidation of the biological properties of guarana extracts.

Santa Helena plantation is located in Maués, in the Central Amazonas region of Brazil and holds the largest

\section{望 Springer}


genetic database for guarana with over 70.000 cultivated plants (AMBEV 2011). However, the production of guarana has been declining in the Amazon State and is actually low compared with that of Bahia State (IBGE 2013). The main factor limiting the production and expansion in the Amazon State is anthracnose, caused by Colletotrichum spp., which is considered the most serious disease of the guarana culture (Bentes and Barreto 2004). Anthracnose causes severe necrosis of young leaves and affects the plant in all growth stages, leading to total drying and decline of the guarana trees in severe cases (Trindade and Poltronieri 1997) and reducing up to $88 \%$ of crop production under traditional cultivation conditions (Araújo et al. 2002a).

Integrated control (the use of resistant clones, culture management and chemical control) has been recommended to prevent anthracnose and reduce production losses. However, there is no effective control of anthracnose disease caused by Colletotrichum in guarana plants (Bentes and Matsuoka 2002; Tavares et al. 2005). Because plants obtained by clonal multiplication have the same genotype and only a portion of them develop anthracnose, a possible explanation for the lack of symptoms may lie in the nature of the microbial community associated with these plants.

Endophytes are defined as microorganisms that inhabit the inner organs and tissues of a plant for at least one period of their life-cycle, without causing visible harm to the host (Azevedo et al. 2000). They can colonize an ecological niche similar to that of phytopathogens and can play an important role in protecting their host against pathogens (Lacava et al. 2006; Mejía et al. 2008; Rajendran et al. 2011). The biocontrol activity of these microorganisms may be due to niche competition (Lacava et al. 2004) and/or through synthesis of allelochemicals including antibiotics, lytic enzymes and siderophores (Araújo et al. 2001; Sturz and Christie 2003). In addition, endophytes can induce systemic resistance in the host plant (Gao et al. 2010). The presence of endophytes has been reported in all host plants (Rosenblueth and MartínezRomero 2006).

Studies regarding endophytic bacteria and their community structure have been performed using culturedependent approaches (Gagne-Bourgue et al. 2013; Xiong et al. 2013; Ji et al. 2014). Nevertheless, in recent years, culture-independent methods associated with cloning and sequencing have provided additional information on whole bacterial endophytic communities and have revealed changes in the structure and species composition due to the presence of abiotic (Peñuelas et al. 2011; Ma et al. 2013) and biotic factors such as the presence of pathogens (Lian et al. 2008; Trivedi et al. 2010). Therefore, the aim of this study was to assess the diversity and composition of endophytic bacterial communities in the phyllosphere of asymptomatic and symptomatic anthracnose Amazon P. cupana plants. We employed culture-dependent based plating and culture-independent methods involving 16S ribosomal RNA PCR-denaturation gradient gel electrophoresis (PCR-DGGE) and clone libraries of $16 \mathrm{~S}$ rRNA. To our knowledge, this is the first report of the endophytic bacterial communities that colonize the phyllosphere of $P$. cupana plants and provides information regarding the association between anthracnose symptoms and endophytic bacteria.

\section{Methods}

\section{Plant material}

Leaf samples were randomly collected from asymptomatic $(\mathrm{n}=5)$ and symptomatic $(\mathrm{n}=5)$ anthracnose $P$. cupana trees (clone BRS-Maués 800) $(\mathrm{n}=5$ leaves for each plant).The collection was conducted in November 2010 in the AmBev's Santa Helena Plantation, Maués/ AM/Brazil, $\left(3^{\circ} 15^{\prime} 10.2^{\prime \prime} \mathrm{S}, 57^{\circ} 44^{\prime} 16.3^{\prime \prime} \mathrm{W}\right)$. After collection, the samples were brought to the lab and processed.

\section{Sample processing}

The leaves collected from each plant were washed individually with tap water and subsequently subjected to a surface-disinfection process by stepwise washing in $70 \%$ ethanol for $1 \mathrm{~min}$, a sodium hypochlorite solution $\left(2 \%\right.$ available $\left.\mathrm{Cl}^{-}\right)$for $2 \mathrm{~min}$, and two rinses in sterilized distilled water (Araújo et al. 2001). To confirm the disinfection process, aliquots of the last sterile-distilled water wash were plated onto $10 \%$ trypticase soy agar (TSA-Merck, Sigma-Aldrich, USA) supplemented with $50 \mu \mathrm{g} \mathrm{ml}^{-1}$ benomyl. The plates were examined for bacterial growth after incubation at $28^{\circ} \mathrm{C}$ for 7 days.

\section{Isolation of endophytic bacteria}

One gram of each disinfected leaf sample was aseptically cut, triturated in $5 \mathrm{ml}$ of sterile phosphate-buffered saline $\left(\mathrm{gl}^{-1}\right) \mathrm{NaCl}, 8 ; \mathrm{Na}_{2} \mathrm{HPO} 4,1.44 ; \mathrm{KH}_{2} \mathrm{PO} 4,0.24 ; \mathrm{KCl}, 0.20$; $\mathrm{pH}$ 7.4) and incubated at $28^{\circ} \mathrm{C}$ under continuous agitation. Appropriate dilutions were plated onto 10\% trypticase soy agar (TSA-Merck) supplemented with benomyl $\left(50 \mu \mathrm{g} \mathrm{ml}^{-1}\right)$, and the plates were incubated at $28^{\circ} \mathrm{C}$ for 7 days. After culturing, the colonies were purified and stored in a $70 \%$ glycerol solution at $-80^{\circ} \mathrm{C}$. The data analysis was performed with the SAS software package (SAS Institute Inc., Cary, NC, USA) using a completely randomized analysis. The bacterial counts were transformed using $\log _{10}(\mathrm{CFU}+1)$ before implementing the ANOVA. Tukey's test was used for further comparison of the means $(P<0.05)$. The bacterial suspensions obtained in this step were subsequently used for total DNA extraction. 


\section{Amplification of the 16S rRNA gene and molecular identification of the isolates}

The 16S rRNA gene partial sequence was amplified using colony PCR. The bacterial colonies were harvested from $10 \%$ trypticase soy agar (TSA-Merck), placed in microtubes containing $80 \mu \mathrm{l}$ of sterilized distilled water and incubated $15 \mathrm{~min}$ at $90^{\circ} \mathrm{C}$. Two microliters of bacterial suspension were used for the DNA source in the PCR reaction. The PCR was conducted in $50 \mu$ containing $10 \times$ buffer $(10 \mathrm{mM} \mathrm{KCl}, 10 \mathrm{mM}$ Tris- $\mathrm{HCl}$, and $\mathrm{pH}$ 8.3) (Fermentas Life Sciences, Brazil), $0.2 \mathrm{mM}$ dNTP, $3.75 \mathrm{mM} \mathrm{MgCl}_{2}$, $2.5 \mathrm{U}$ Taq DNA polymerase (Fermentas Life Sciences, Brazil) and $0.2 \mu \mathrm{M}$ forward P027F (5'GAGAGTTTGATCCTGGCTCAG $3^{\prime}$ ) primer (Heuer and Smalla 1997). The conditions for the amplification of 16S rRNA sequences consisted of an initial denaturation step of $94^{\circ} \mathrm{C}$ for $4 \mathrm{~min}$, followed by 35 cycles of $94^{\circ} \mathrm{C}$ for $30 \mathrm{~s}, 62.5^{\circ} \mathrm{C}$ for $1 \mathrm{~min}, 72^{\circ} \mathrm{C}$ for $1 \mathrm{~min}$ and a final extension of $10 \mathrm{~min}$ at $72^{\circ} \mathrm{C}$. The PCR products were analyzed by electrophoresis using $1 \%(\mathrm{w} / \mathrm{v})$ agarose gel stained with ethidium bromide. The 16S rRNA gene PCR fragments were purified with polyethylene glycol (PEG) $(20 \%$ PEG 8000; $2.5 \mathrm{mM} \mathrm{NaCl}$ ) and sequenced at the Human Genome Research Center (HGRC) (Institute of Biosciences, University of São Paulo, São Paulo, SP, Brazil).

The 16S rRNA gene sequences obtained were compared with sequences available in the Ribosomal Database Project (http://rdp.cme.msu.edu) and classified using the RDP Classifier tool (http://rdp.cme.msu.edu/ classifier/classifier.jsp). Significant differences among taxonomic groups in asymptomatic and symptomatic anthracnose samples were checked using the Lib Compare tool (http://rdp.cme.msu.edu/comparison/comp. jsp).

\section{Extraction of total DNA from plant samples}

Five hundred milliliters of each leaf extract that contained endophytic bacteria (suspensions obtained from one gram of surface-disinfected leaf samples, as described above) were used for total DNA extraction using the MoBio Power Soil DNA extraction kit (MoBio Laboratories, Carlsbad, CA, USA) according to the manufacturer's recommendations. The total DNA was visualized by electrophoresis on a $1 \%(\mathrm{w} / \mathrm{v})$ agarose gel stained with ethidium bromide.

\section{PCR-DGGE analysis}

The first PCR was conducted with primers $799 \mathrm{~F}\left(5^{\prime}\right.$ AAC MGG ATT AGA TAC CCK G $3^{\prime}$ ) (Chelius and Triplett 2001) and $1492 \mathrm{R}$ (5' TAC GYT ACC TTG TTA CGA CT $\left.3^{\prime}\right)$. The PCR mixture $(50 \mu \mathrm{l})$ consisted of $1 \mu \mathrm{l}$ of total DNA obtained from plant samples, $10 \times$ buffer $(10 \mathrm{mM}$ $\mathrm{KCl}, 10 \mathrm{mM}$ Tris-HCl, pH 8.3 (Fermentas Life Sciences,
Brazil), $0.4 \mu \mathrm{M}$ each primer, $0.25 \mathrm{mM}$ dNTP, $3.75 \mathrm{mM}$ $\mathrm{MgCl}_{2}, 1 \%(\mathrm{w} / \mathrm{v})$ formamide and $2.5 \mathrm{U}$ Taq DNA polymerase (Fermentas Life Sciences, Brazil). A PCR mixture without DNA was used as the negative control in all PCR experiments. The PCR reactions were performed in a PT-200 thermocycler (MJ Research, USA) programmed to $95^{\circ} \mathrm{C}$ for $3 \mathrm{~min}$, followed by 35 cycles of $94^{\circ} \mathrm{C}$ for $20 \mathrm{~s}$, $53^{\circ} \mathrm{C}$ for $40 \mathrm{~s}, 72^{\circ} \mathrm{C}$ for $40 \mathrm{~s}$ and a final extension of step of $7 \mathrm{~min}$ at $72^{\circ} \mathrm{C}$. The nested PCR was performed using $1 \mu \mathrm{l}$ of the PCR product from the first reaction and $0.4 \mu \mathrm{M}$ primers $\mathrm{U} 96{ }^{\perp}{ }^{\perp} \mathrm{CG}$ and $\mathrm{R} 1378 \mathrm{R}$ (Heuer and Smalla 1997), with a denaturation step of $94^{\circ} \mathrm{C}$ for $4 \mathrm{~min}$, followed by 35 cycles of $94^{\circ} \mathrm{C}$ for $1 \mathrm{~min}, 56^{\circ} \mathrm{C}$ for $1 \mathrm{~min}, 72^{\circ} \mathrm{C}$ for $1 \mathrm{~min}$ and a final extension of step of $10 \mathrm{~min}$ at $72^{\circ} \mathrm{C}$. The PCR products $(450 \mathrm{bp})$ were analyzed by electrophoresis in a $1 \%(\mathrm{w} / \mathrm{v})$ agarose gel stained with ethidium bromide.

The PCR-DGGE analysis was based on the method described by Muyzer and Smalla 1998 and adapted by Araújo et al. (2002b) using an Ingeny PhorU apparatus (Ingeny, Goes, The Netherlands). The PCR products (473 bp) in equal amounts (about) were loaded onto $6 \%(\mathrm{w} / \mathrm{v})$ polyacrylamide gels in $0.5 \times \mathrm{TAE}$ buffer (20 mM Tris-acetate, $0.5 \mathrm{mM}$ EDTA, and $\mathrm{pH}$ 7.4). The polyacrylamide gels were prepared with denaturing gradients ranging from 35 to $65 \%$, where $100 \%$ denaturant contained $7 \mathrm{M}$ urea and $40 \%$ formamide. Electrophoresis was conducted at $100 \mathrm{~V}$ and $60^{\circ} \mathrm{C}$ for $15 \mathrm{~h}$. The gel was stained with silver nitrate (Blum et al. 1987) and photographed under a white light transilluminator (VariQuest 100, FOTODYNE Incorporated, Hartland, WI, USA).

The DGGE profiles were analyzed with BioNumerics (Applied Maths NV). The images were normalized using markers, and matrices of the data sets, based on the presence or absence of bands, were generated using PRIMER 6 for Windows (PRIMER-E, Plymouth, United Kingdom). Similarity coefficients were calculated using the Bray-Curtis coefficient. The generated similarity matrices were used to construct nonmetric multidimensional scaling (NMDS) ordinations to observe patterns of similarity between samples, and the significance of these patterns was tested using ANOSIM statistics (Clarke and Green 1988). The calculation of similarity coefficients and ANOSIM statistics were conducted using PRIMER 6.

\section{Clone libraries construction}

Ten clone libraries were generated from PCR products of the $16 \mathrm{~S}$ rRNA gene. The PCR mixtures $(50 \mu \mathrm{l})$ contained $1 \mu$ template DNA (5-10 ng), $10 \times$ buffer $(10 \mathrm{mM} \mathrm{KCl}$, $10 \mathrm{mM}$ Tris-HCl, pH 8.3 (Fermentas Life Sciences, Brazil), $0.4 \mu \mathrm{M}$ each primer $799 \mathrm{~F}$ (5' AAC MGG ATT AGA TAC CCK G 3') (Chelius and Triplett 2001) and 1492 R (5' TAC GYT ACC TTG TTA CGA CT $\left.3^{\prime}\right), 0.2 \mathrm{mM}$ 
dNTP, $3.75 \mathrm{mM} \mathrm{MgCl}_{2}, 1 \%(\mathrm{w} / \mathrm{v})$ BSA (bovine serum albumin) and 2.5 U Taq DNA polymerase (Fermentas Life Sciences, Brazil). These primers are specific to bacteria and have a low affinity for chloroplast DNA. The PCR amplification was performed with an initial denaturation step at $95^{\circ} \mathrm{C}$ for $3 \mathrm{~min}$, followed by 25 cycles of $94^{\circ} \mathrm{C}$ for $20 \mathrm{~s}, 53^{\circ} \mathrm{C}$ for $40 \mathrm{~s}, 72^{\circ} \mathrm{C}$ for $40 \mathrm{~s}$ and a final extension of step of $7 \mathrm{~min}$ at $72^{\circ} \mathrm{C}$. One microliter of the PCR product was used in a second reaction with the primers $968 \mathrm{~F}$ (without GC-clamp) and $1387 \mathrm{R}$ in similar PCR mixture conditions and at a final volume of $50 \mu \mathrm{l}$. The nested PCR was conducted with an initial denaturation step of $94^{\circ} \mathrm{C}$ for $4 \mathrm{~min}$, followed by 35 cycles of $94^{\circ} \mathrm{C}$ for $1 \mathrm{~min}, 62.5^{\circ} \mathrm{C}$ for $1 \mathrm{~min}, 72^{\circ} \mathrm{C}$ for $2 \mathrm{~min}$ and a final extension of $72^{\circ} \mathrm{C}$ for $10 \mathrm{~min}$. The PCR mixture without DNA was used as a negative control in all PCR experiments.

PCR products of about $433 \mathrm{bp}$ were purified using the GFX ${ }^{\mathrm{m}}$ PCR DNA and Gel Band Purification Kit (GE Healthcare, UK). Ligation into pGEM $^{\circ}-\mathrm{T}$ Easy Vector System II (Promega, Madison, WI, USA) and transformation into competent Escherichia coli DH5 $\alpha$ cells (Promega, Madison, WI, USA) were performed according to the manufacturer's instructions. The extracted plasmid DNA was subjected to sequencing with the 1378 $\mathrm{R}$ primer and BigDye ${ }^{\bullet}$ Terminator v 3.1 Cycle Sequencing Kit (Applied Biosystems, Foster City, CA, USA). The sequencing was performed in an ABI 3730 DNA Analyser (Applied Biosystems) at the Human Genome Research Center (HGRC) (Institute of Biosciences, University of São Paulo, São Paulo, SP, Brazil).

\section{Taxonomic assignment and phylogenetic analysis}

The nucleotide sequences were analyzed for quality and trimmed using the CodonCode Aligner program (http:// www.codoncode.com/aligner/). Only sequences with a quality parameter $>20$ (i.e., less than one error in 100 nucleotides) were considered (Ewing et al. 1998). Chimeras and chloroplast sequences were checked using Bellerophon v.3 on the Greengenes chimera-check tool (http:// greengens.lbl.gov) and the MG-RAST metagenomics analysis server (http://metagenomics.anl.gov/metagenomics.cgi? page $=$ Home), respectively. The phylogenetic affiliation was inferred by RDP classifier (http://rdp.cme. msu.edu/classifier/classifier.jsp).

A phylogenetic tree was constructed using Mega 4 software (Tamura et al. 2007). For this process, bacterial $16 \mathrm{~S}$ rRNA gene sequences were chosen randomly based on classification of sequences representative of each genera and aligned with type sequences present in the RDP Project database (http://rdp.cme.msu.edu/index. jsp) using the Clustal W (http://www.ebi.ac.uk/Tools/ $\mathrm{msa} /$ clustalw2/). The analyses were based on the Neighbor-Joining method following the Jukes-Cantor model for substitution of nucleotides. The robustness of the branches was tested using bootstrap analysis with 1,000 replications and the consensus tree edition was held using ITOL (http://itol.embl.de/).

Significant differences among taxonomic groups in asymptomatic and symptomatic anthracnose plants were checked using the Lib Compare tool (http://rdp.cme. msu.edu/comparison/comp.jsp).

\section{Richness estimation and diversity of total endophytic bacterial communities}

Using MOTHUR v.1.20.3 software (http://www.mothur. org) (Schloss 2009), the sequences were aligned and the evolutionary distances were calculated using the JukesCantor parameter (Jukes and Cantor 1969). The generated matrix was used to assign sequences to operational taxonomic units (OTUs) and to generate estimations of the Chao1 richness, Shannon-Weaver and Simpson diversity index (at 100, 97, 95 and 91\% similarity levels), rarefaction curves and heatmaps. The LIBSHUFF software was used to determine the significant differences between asymptomatic and symptomatic anthracnose plants (Schloss et al. 2004).

\section{Nucleotide sequences accession numbers}

The 16S rRNA gene sequences obtained from the isolation methodology and construction of clone libraries were deposited in the GenBank database with accession numbers KC493265 to KC493350 and KC348605 to KC349130, respectively.

\section{Results}

\section{Determination of culturable endophytic bacteria}

The diversity of culturable endophytic bacteria was assessed in samples of leaves from $10 P$. cupana plants. The bacterial densities were different $(P<0.05)$ according to the phytosanitary condition and ranged from $10^{4}$ to $10^{5} \mathrm{CFU} \mathrm{g}^{-1}$ (fresh leaf weight) for asymptomatic and symptomatic anthracnose plants, respectively. A total of 86 sequences were examined on the basis of 16S rRNA gene sequencing. The endophytic isolates were assigned, in order, to the Firmicutes (48.8\%), Proteobacteria (30.2\%), Actinobacteria (19.7\%) and Bacteroidetes (1.16\%) phyla. With the exception of the Bacteroidetes, which was observed only in symptomatic anthracnose plants, all of the other phyla were present in all of the plants. Firmicutes comprised the majority of the isolates and was predominant in asymptomatic plants $\left(2.40 \mathrm{E}^{-4}\right)$ (Figure 1a). The most abundant classes (30.2\% of Proteobacteria) were Gammaproteobacteria (6.9\%) and Alphaproteobacteria (23.3\%).

The isolates could also be assigned to the genera Bacillus (37.2\%), Microbacterium (10.5\%), Brevibacillus (8.1\%), 

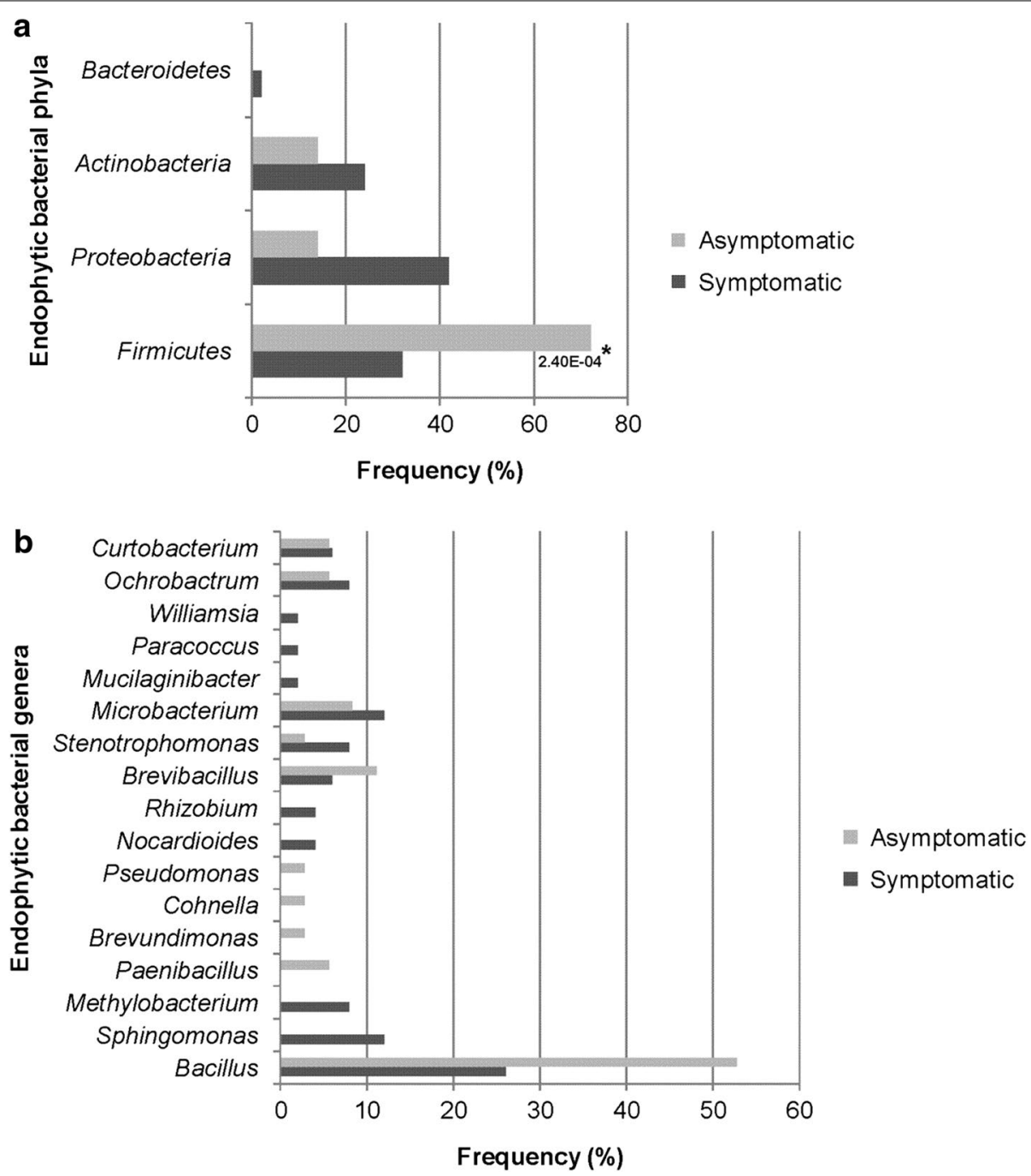

Figure 1 Relative frequency distribution of phyla $(\mathbf{a})$ and genera $(\mathbf{b})$ of endophytic bacteria isolated from asymptomatic and symptomatic anthracnose leaf samples of P. cupana $(n=86)$. A significant difference $\left({ }^{*} P<0.05\right)$ was observed at the phylum level for Firmicutes in asymptomatic plants.

Sphingomonas (6.9\%), Ochrobactrum (6.9\%), Stenotrophomonas (5.8\%), Curtobacterium (5.8\%), Methylobacterium (4.7\%), Paenibacillus (2.3\%), Rhizobium (2.3\%), and Nocardioides (2.3\%). Additionally, we found Cohnella, Brevundimonas, Pseudomonas, Paracoccus, Williamsia and Mucilaginibacter, but they represented only $1.2 \%$ of genera assessed. The presence, absence or prevalence of each genus also varied according to the physiological state of the plants (Figure 1b). No significant differences were observed among isolates at the genus level.

\section{PCR-DGGE analysis}

The 16S rRNA gene-based PCR-DGGE analysis revealed the presence of endophytic bacteria in all leaf samples
(Figure 2) NMDS analysis of the DGGE profiles showed that the structure of endophytic bacterial communities of asymptomatic and symptomatic anthracnose plants are different and suffered significant impact due to disease (ANOSIM R $=0.972, P<0.001$ ) (Figure 3 ).

\section{$16 S$ rRNA clone library analysis}

After examining the sequences for quality and the presence of chimeras and chloroplasts, a total of 526 clone sequences were selected, with 260 and 266 from symptomatic anthracnose and asymptomatic plants, respectively.

Using the RDP classifier, Proteobacteria (70.65\%), Actinobacteria (23.68\%), Firmicutes (4.69\%), Acidobacteria (0.79\%) and Bacteroidetes (0.19\%) were the dominant phyla. Clones representing Bacteroidetes were found only 

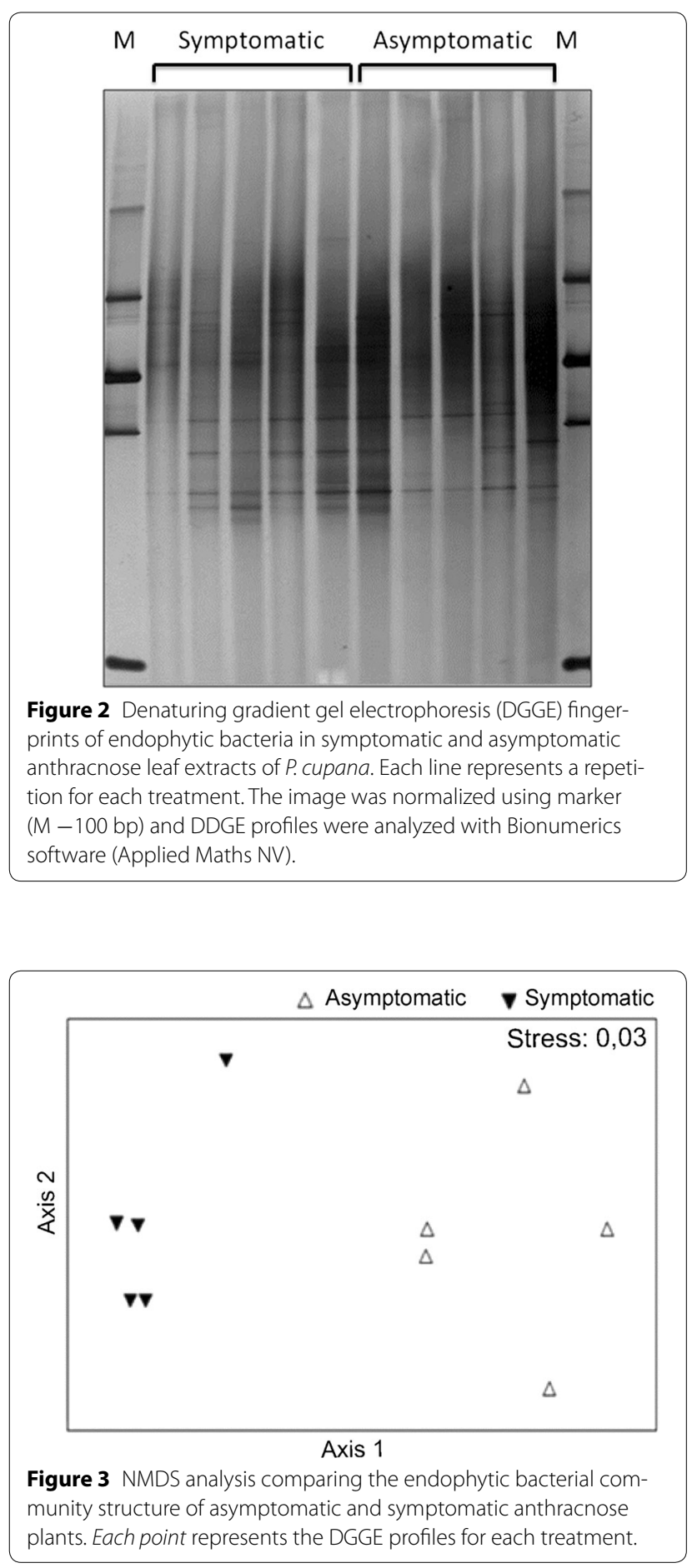

in the clone library of the asymptomatic plants, whereas the phylum Acidobacteria was represented only in symptomatic anthracnose plants (Figure 4). Among the sequences similar to Proteobacteria, 356 were associated with Gammaproteobacteria (54.7\%), Betaproteobacteria (38.48\%) and Alphaproteobacteria (6.74\%).

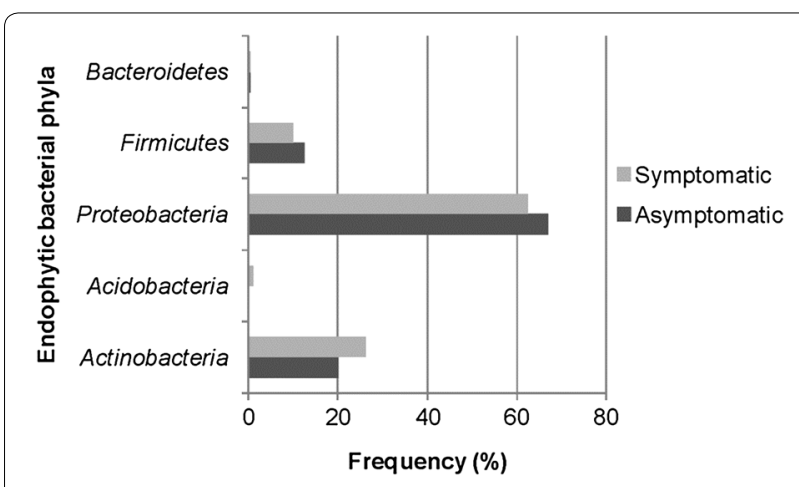

Figure 4 Composition of 16S rRNA gene clone libraries at the phylum level determined by similarity with RDP Classifier tool $(n=526)$.

Furthermore, 397 sequences were classified to the genus level. Among these sequences, 34 were randomly chosen as representatives in the phenetic analysis. The distribution of the represented sequences is illustrated by a proportionally sized bar and color corresponding to the treatment of the origin (Figure 5). These sequences were aligned with "type" sequences obtained from the RDP database and affiliated with 34 bacterial genera, which were mainly represented by Hydrogenophilus (25.4\%), Pseudomonas (15.8\%), Propionibacterium (10.3\%), Acinetobacter (6.8\%), and Rubrobacter (4.5\%), and other groups were present in minor proportions as Rothia (4.2\%), Arsenophonus (3.7\%), Atopostipes (3.7\%), Burkholderia (3.5\%), Neisseria (3.2\%), Haemophilus (2.2\%), Paracoccus (2.2\%) and Aquicella (2\%). Another 21 genera represented less than $1 \%$ of the total.

The 16S rRNA gene clone libraries were also compared using the Lib Compare tool (Figure 6). Significant differences $(P<0.05)$ were observed at the genera level among Neisseria $\left(1.4 \mathrm{E}^{-4}\right)$, Haemophilus $\left(2.1 \mathrm{E}^{-3}\right)$ and Arsenophonus $\left(3.6 \mathrm{E}^{-5}\right)$ found only in asymptomatic plants, Aquicella $\left(3.5 \mathrm{E}^{-3}\right)$ found only in symptomatic anthracnose plants, and Pseudomonas $\left(1.1 \mathrm{E}^{-3}\right)$ was observed in both treatments but at the highest frequency in asymptomatic plants.

\section{Richness estimation and diversity of total endophytic bacterial communities}

Rarefaction analyses were performed using cut-off criteria for grouping OTUs at species (97\%), genus (95\%) and order $(91 \%)$ levels. The curves showed a tendency to stabilize at the $97 \%$ level for both asymptomatic and symptomatic anthracnose plants and reached a plateau at the 91\% level of similarity (Figure 7). This indicates that the number of sequences analyzed is large enough to reflect the diversity of culturable and unculturable endophytic bacterial in P. cupana. 


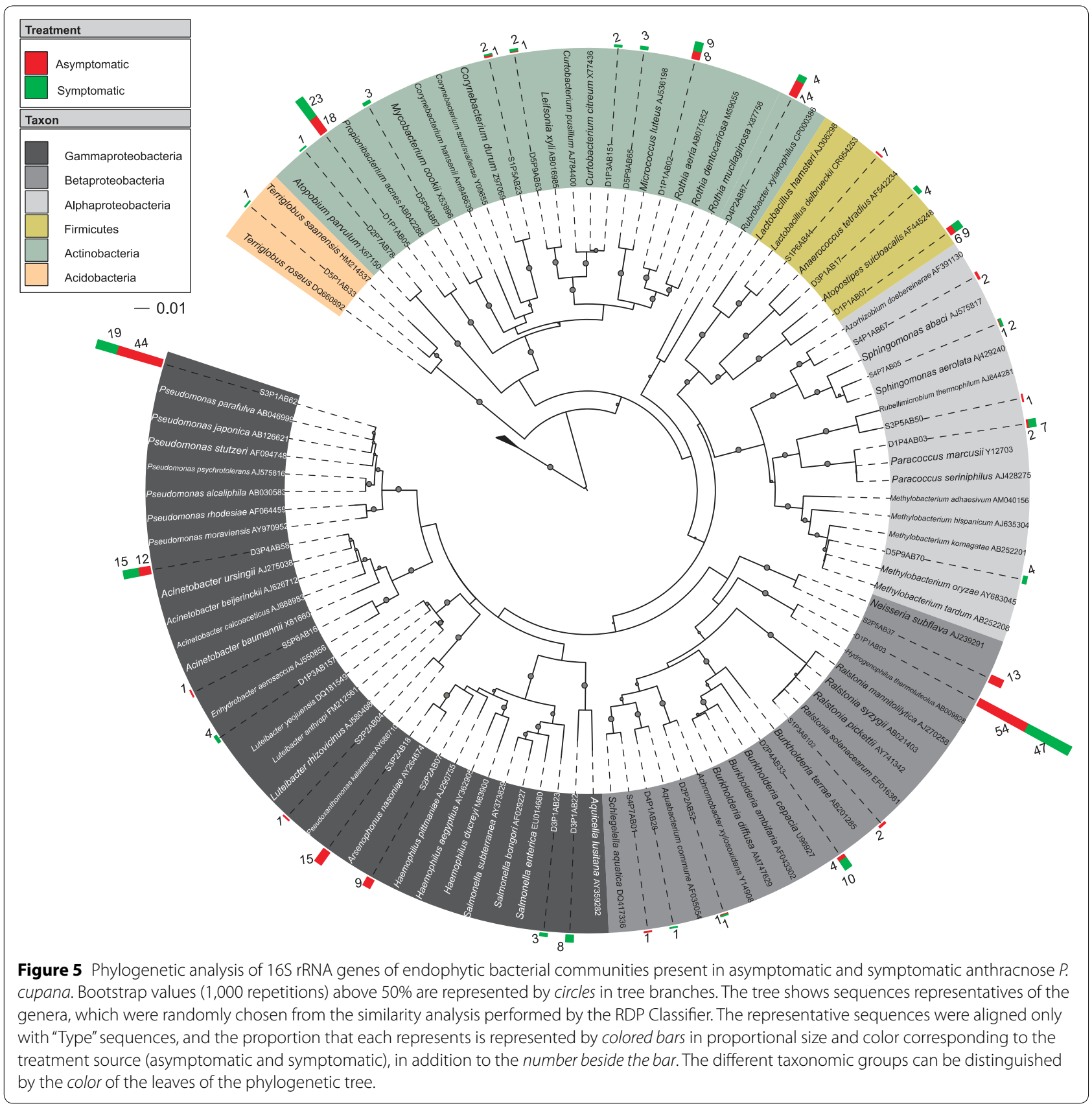

Using the same cut-off criteria for the grouping of OTUs employed for the construction of rarefaction curves, Chao1 richness and Shannon-Weaver $(\mathrm{H})$ and Simpson diversity indices could also be determined. Chao1 richness estimations $(P<0.05)$ did not differ significantly between asymptomatic and symptomatic anthracnose plants. However, Shannon-Weaver $(\mathrm{H})$ at the 97-91\% levels and the Simpson index at the 91\% level for symptomatic anthracnose plants were significantly higher than those observed for asymptomatic plants (Additional file 1: Table S1).

The analysis of richness using the Chao1 estimator indicated that both symptomatic and asymptomatic plants did not differ significantly. However, the Shannon-Weaver $(\mathrm{H})$ and Simpson indices indicate that the diversity of the OTUs corresponding order (91\%) is significantly higher in symptomatic plants. Moreover, the Shannon-Weaver $(\mathrm{H})$ indices also indicated the 


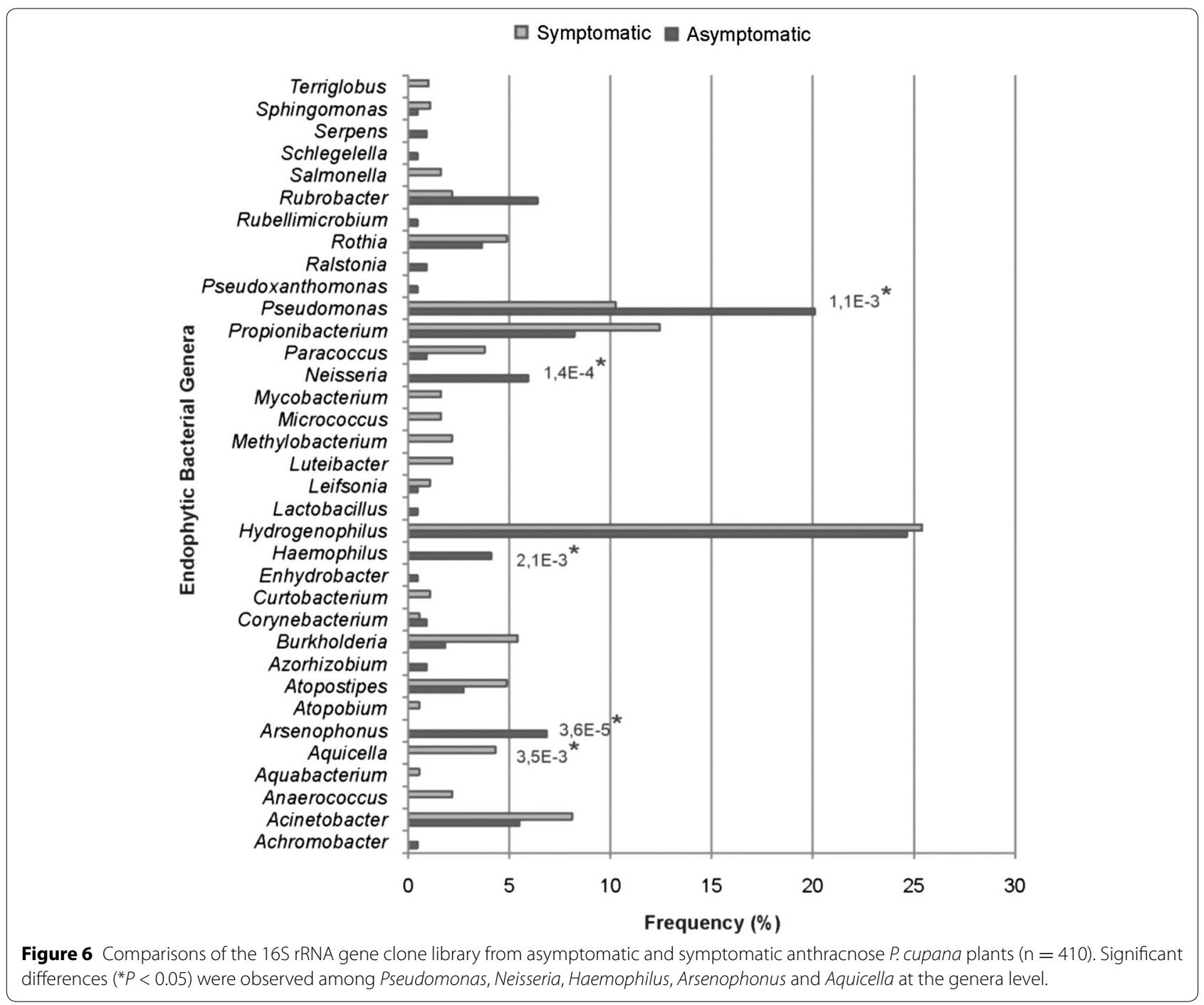

highest species diversity (97\%) in plants symptomatic for anthracnose.

Heatmaps for the relative abundance of OTUs were also generated (Figure 8). An analysis at the $97 \%$ level of similarity revealed the presence of 140 OTUs in symptomatic anthracnose and 116 OTUs in asymptomatic plants, with $10.34 \%$ of the OTUs shared between plants. When analyzed at 95\%, 107 OTUs were observed on symptomatic anthracnose and 93 on asymptomatic plants, with 14.28\% shared (Additional file 1: Table S1). A density analysis of groups within the OTUs revealed the presence of a more dense but non-shared group between the treatments at the $95 \%$ level of similarity.

A cross-comparison of asymptomatic and symptomatic anthracnose plants using LIBSHUFF statistics revealed that the endophytic bacterial community present in asymptomatic plants is significantly different from the symptomatic anthracnose $(P<0.0001)$. These data are in accordance with NMSD and ANOSIM analysis of DGGE profiles.

\section{Discussion}

To investigate the endophytic bacterial communities living in the phyllosphere of asymptomatic and symptomatic anthracnose Amazon P. cupana plants, we used culture-dependent and culture-independent approaches. The application of both methods in parallel (for the same samples) for assessing bacterial communities in leaves has been previously reported (Araújo et al. 2002b; Ulrich et al. 2008; Yashiro et al. 2011) and is important in analyzing microbial diversity because the analysis based on the culture-dependent method may underestimate the diversity (Rasche et al. 2006; Jackson et al. 2013). In fact, we found fewer endophytic bacteria using the culturedependent method than the $16 \mathrm{~S}$ rRNA clone libraries. In addition to the accuracy of the methodologies, several 


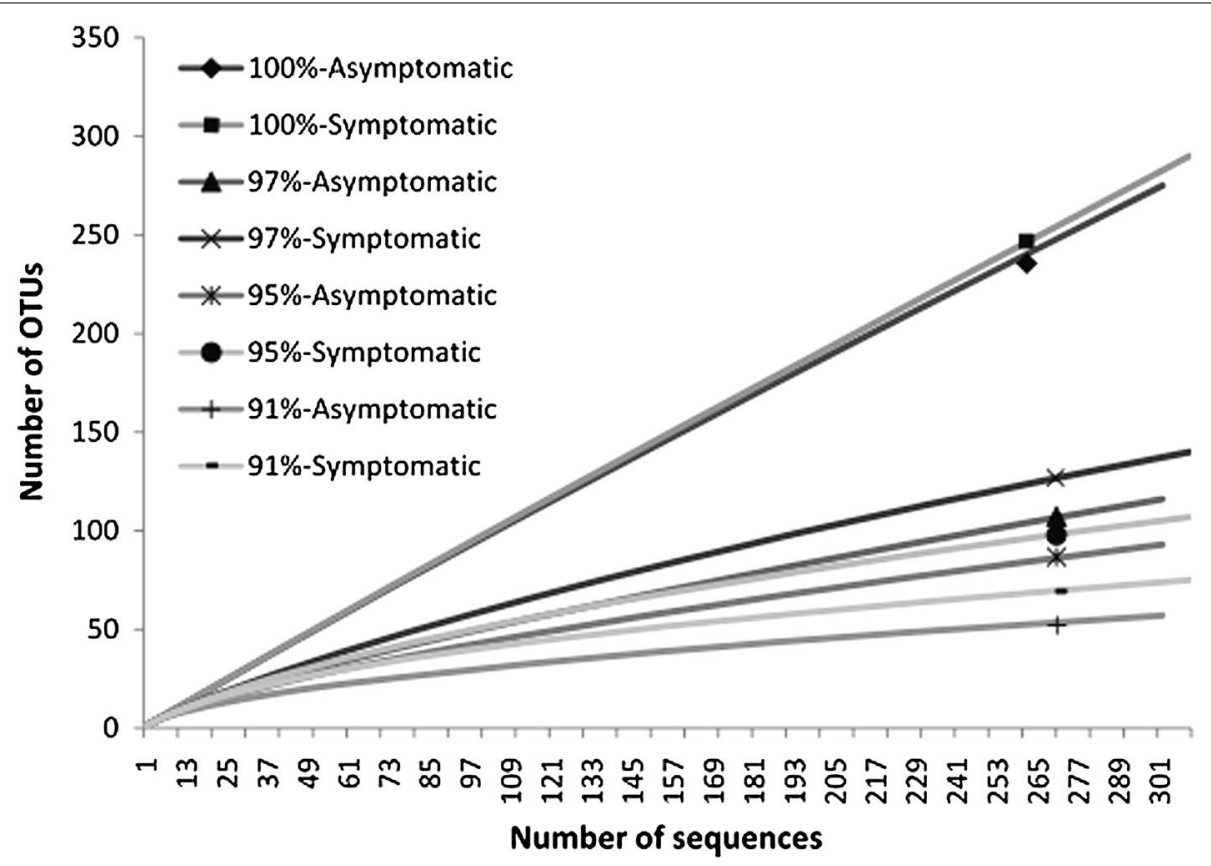

Figure 7 Rarefaction curves of the 16S rRNA gene of culturable and unculturable endophytic bacterial communities associated with asymptomatic and symptomatic anthracnose P. cupana leaves.

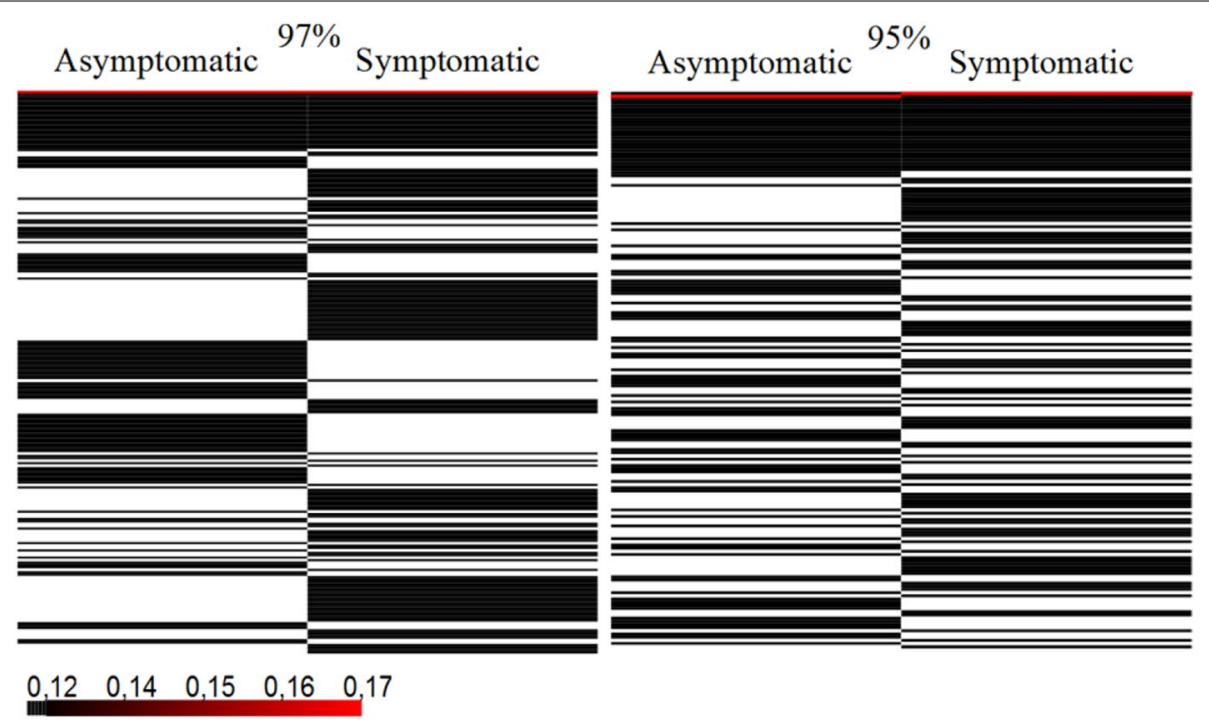

Figure 8 Heatmaps for the relative abundance of operational taxonomic units (OTUs) for the 16S rRNA gene of P. cupana leaf-associated endophytic bacteria $(n=612)$. The relative abundance for the OTUs at 97 and $95 \%$ levels of similarity is shown at the left and right side, respectively. Sideby-side lines represent OTUs shared by asymptomatic and symptomatic anthracnose plants. The OTUs with a low frequency of sequences (less than 0.14 ) are represented by black lines, while OTUs with a higher frequency of sequences (higher than 0.16 ) are represented by red lines.

abiotic and biotic environmental factors may affect the plant physiology and consequently the assessed microbial communities. In this context, the presence of pathogens has been considered an important factor in the restructuring of endophytic bacterial communities (Araújo et al.
Araújo et al. 2002a, b; Bulgari et al. 2011; Trivedi et al. 2010), which can play an important role in host plant protection (Lacava et al. 2006; Mejía et al. 2008).

When we employed PCR-DGGE fingerprinting to analyze the overall diversity of endophytic bacterial 
communities in $P$. cupana, we verified that asymptomatic and symptomatic anthracnose plants differed significantly (ANOSIM, $R=0.972$ ) in their structure. Thus, the presence of Colletotrichum in P. cupana seems to be important to cause shifts in the microbial communities. Trivedi et al. (2010) suggested that these shifts can occur by mechanisms such as competition for nutrients and space, microbial cross talk and changes in the niche environment.

Regarding the identity of the obtained isolates and clones, we verified the presence of Proteobacteria, Firmicutes, Actinobacteria, Bacteroidetes and Acidobacteria phyla, which are reported in a phyllosphere (Romero et al. 2014; Rastogi et al. 2012; Bodenhause et al. 2013).

Some differences were observed in relation to the frequency and distribution of phyla in the samples analyzed. The Firmicutes phylum (48.8\%), represented mainly by Bacillus (37.2\%), was significantly more isolated from asymptomatic plants $\left(2.40 \mathrm{E}^{-4}\right)$, followed by Proteobacteria (30.2\%). This result differs from those observed in other studies, in which Proteobacteria has been isolated as the dominant phylum in the phyllosphere of other hosts (Costa et al. 2012). However, sequences affiliated with Proteobacteria (70.65\%) represented the largest fraction of clones, and corroborated with studies that have reported this phylum as the most common in leaves when obtained by culture-independent approaches (Romero et al. 2014; Sagaram et al. 2009; Kim et al. 2012). Among the members of Proteobacteria, Pseudomonas was significantly assessed $\left(1.1 \mathrm{E}^{-3}\right)$ in asymptomatic plants.

The bacteria representing Firmicutes and Proteobacteria found in our study have also been observed in high frequency colonizing the leaves of other plants without disease symptoms (Bodenhause et al. 2013; Melnick et al. 2011; Paz et al. 2012). This finding could make Bacillus and Pseudomonas interesting biological control agents against phytopathogens by various mechanisms that may include induction of systemic resistance in the host plant and antibiosis (Choudhary and Johri 2009; Krid et al. 2010). In this context, we speculate that there is an association of these endophytic bacteria with the resistance of $P$. cupana to anthracnose, which could be limiting the invasion and the establishment of Colletotrichum in the asymptomatic plants.

Other clones representative of Proteobacteria significantly assessed in asymptomatic plants were Neisseria $\left(1.4 \mathrm{E}^{-4}\right)$, Haemophilus $\left(2.1 \mathrm{E}^{-3}\right)$ and Arsenophonus $\left(3.6 \mathrm{E}^{-5}\right)$. Although Neisseria is typically associated as a human pathogen, this genus has been found inhabiting the interior of plants (Videira et al. 2013). Haemophilus, also described as a human pathogen, was associated with the hyphae of endophytic fungi isolated from Cupressus arizonica (Hoffman and Arnold 2010). Arsenophonus genus, however, has been described as a group of insect intracellular symbionts (Nováková et al. 2009). To our knowledge, this is the first association of Haemophilus and Arsenophonus as endophyte of the phyllosphere.

In the clone libraries of symptomatic anthracnose plants, the Aquicella $\left(3.5 \mathrm{E}^{-3}\right)$ genus was significantly assessed. These bacteria are typically found in water samples (Perkins et al. 2009; Santos et al. 2003) but were recently found as endophytes in clone libraries of the root of Pennisetum purpureum (Videira et al. 2013). Disease abatement is possible using the establishment of some endophytes in the host plant or the allowing endophytes to trigger the disease by synergistic interaction with a pathogen (Araújo et al. 2002b). However, we cannot affirm whether this would occur in P. cupana plants colonized by Aquicella.

Although examined by isolation and cloning, the presence of Actinobacteria and Bacteroidetes phyla in both asymptomatic and symptomatic anthracnose plants was not significant in relation to the phytosanitary condition. Actinobacteria was the third most isolated phylum (19.7\%) and the second most identified in the clone libraries (23.67\%) and typically established associations with the phyllosphere of other hosts (Bodenhause et al. 2013; López-Velasco et al. 2011). Bacteroidetes was the least isolated phylum $(1.16 \%)$ from symptomatic anthracnose plants and the least identified in the clone libraries of asymptomatic plants (0.19\%). Costa et al. (2012) also isolated Bacteroidetes from the leaves of Phaseolus vulgaris at low frequency. In contrast, Jackson et al. (2013) reported this phylum as one of most prevalent in the phyllosphere of vegetables when identified by a cultureindependent method.

Acidobacteria was the unique phylum that was not observed among isolates. Although typically found in the rhizosphere (Gottel et al. 2011; Bulgarelli et al. 2013), we identified this phylum at low frequency $(0.79 \%)$, inhabiting the phyllosphere of symptomatic anthracnose $P$. cupana. Recently, Acidobacteria was also obtained as endophytes of leaves by pyrosequencing (Romero et al. 2014), which confirmed our data obtained by the cultureindependent method.

Alphaproteobacteria (23.3\%) was the most abundant class of Proteobacteria among isolates, followed by Gammaproteobacteria (6.9\%). In contrast, a high number of Gammaproteobacteria (54.7\%) was found in the clone libraries, followed by Betaproteobacteria (38.48\%) and Alphaproteobacteria (6.74\%). Similar to what we found in our research, Alphaproteobacteria and Gammaproteobacteria are described in some studies as dominant in the phyllosphere (Romero et al. 2014; Jin et al. 2013). Betaproteobacteria can form a considerable part of the 
bacterial communities in some situations (Jackson et al. 2013). These classes did not differ significantly in relation to the phytosanitary condition.

Our rarefaction analysis showed that the number of isolates and clones evaluated was a sufficient representation of the sampling effort of endophytic bacterial communities in P. cupana. Asymptomatic and symptomatic anthracnose plants did not differ in relation to their species richness. However, the Shannon-Weaver and Simpson index showed higher microbial diversity in symptomatic anthracnose plants. Heatmaps for the relative abundance of OTUs also revealed a higher density in symptomatic anthracnose plants. LIBSHUFF statistics confirmed these differences in the composition of endophytic bacteria between asymptomatic and symptomatic anthracnose plants.

Reiter et al. (2002) reported an increase in the diversity of endophytic bacteria in potato plants in response to Erwinia carotovora infection. Lian et al. (2008) also demonstrated that a tissue culture banana plantlet infected with Fusarium oxysporum had an increase in endophytic bacterial diversity. The infection of the host plant by some phytopathogens may involve the production of cell wall-degrading enzymes (Barras et al. 1994; Annis and Goodwin 1997), and the onset of lesions can allow the entry of other bacteria into the plant (Trivedi et al. 2010). In addition, the pathogen infection may affect plant physiology by favoring the establishment of some endophytic bacterial groups (Hallmann et al. 1998). In this context, the possible physiological changes in P. cupana due to anthracnose seem to be reflected in the distribution of endophytic bacteria between asymptomatic and symptomatic anthracnose plants.

For the first time, we have described the endophytic bacterial diversity in the phyllosphere of Amazon $P$. cupana plants. Our results suggest a possible interaction between anthracnose and the endophytic bacterial communities evaluated. Beneficial bacteria found in asymptomatic plants open the possibility for a better understanding of the mechanisms involved in the resistance of P. cupana to Colletotrichum spp. and the development of future strategies of biocontrol.

\section{Additional files}

Additional file 1: Table S1. Number of OTUs, diversity and richness estimations for $16 \mathrm{~S}$ r RNA gene.

\footnotetext{
Author details

${ }^{1}$ Department of Genetics, "Luiz de Queiroz" College of Agriculture, University of São Paulo, Av. Pádua Dias 11, PO BOX 83, Piracicaba, SP 13400-970, Brazil. ${ }^{2}$ Department of Microbiology, Institute of Biomedical Sciences, University of São Paulo, Av. Prof. Lineu Prestes, 1374-Ed. Biomédicas II, Cidade Universitária, São Paulo, SP 05508-900, Brazil. ${ }^{3}$ Molecular Diagnostic Laboratory,
}

Biotechnology Division, Federal University of Amazon, Av. Gal. Rodrigo Octávio Jordão, 3000, Manaus, AM 69.077-000, Brazil. ${ }^{4}$ Department of Plant Pathology and Nematology, "Luiz de Queiroz" College of Agriculture, University of São Paulo, Av. Pádua Dias 11, Piracicaba, SP 13418-900, Brazil. ${ }^{5}$ Center of Biological Sciences and Health, Federal University of São Carlos, Via Washington Luís km 235, PO BOX 676, São Carlos, SP 13565-905, Brazil.

\section{Acknowledgements}

This work was supported by grants from CNPq (509577/2010-5) and FAPESP/ FAPEAM (09/53376-2).

Compliance with ethical guidelines

\section{Competing interests}

The authors declare that they have no competing interest.

Received: 8 April 2015 Accepted: 13 May 2015

Published online: 13 June 2015

\section{References}

AMBEV (2011) Relatório Anual. IOP Publishing PhysicsWeb. http://ri.ambev. com.br/arquivos/ambev-_RA_2011.pdf. Accessed 20 Sep 2014

Ângelo PCSA, Nunes-Silva CG, Brígido MM, Azevedo JSN, Assunção EN, Sousa ARB et al (2008) Guarana (Paullinia cupana var. sorbilis), an anciently consumed stimulant from the Amazon rain forest: the seeded-fruit transcriptome. Plant Cell Rep 27:117-124

Annis S, Goodwin PH (1997) Recent advances in the molecular genetics of the plant cell wall-degrading enzymes produced by plant pathogenic fungi. Eur J Plant Pathol 103:1-14

Araújo WL, Saridakis HO, Barroso PAV, Aguilar-Vildoso Cl, Azevedo JL (2001) Variability and interactions between endophytic bacteria and fungi isolated from leaf tissues of citrus rootstocks. Can J Microbiol 47:229-236. doi:10.1139/cjm-47-3-229

Araújo JCA, Pereira JCR, Gasparotto L, Atroch AL (2002a) Surto de antracnose (Colletotrichum guaranicola) do guaranazeiro (Paullinia cupana var. sorbilis) no Estado do Amazonas. In: Abstracts of the XXXV Congresso Brasileiro de Fitopatologia, Recife/PE, 27: (supplement) S78 August 2002

Araújo WL, Macon J, Maccheroni WJ, Van Elsas JD, Van Vuurde JWL (2002b) Diversity of endophytic bacterial populations and their interaction with Xylella fastidiosa in citrus plants. Appl Environ Microbiol 68:906-4914. doi:10.1128/AEM.68.10.4906-4914

Azevedo JL, Maccheroni WJ, Pereira JO, Araújo WL (2000) Endophytic microorganisms: a review on insect control and recent advances on tropical plants. Electron J Biotechnol 3:40-65

Barras F, Van Gijsegem F, Chatterjee AK (1994) Extracellular enzymes and pathogenesis of soft-rot Erwinia. Annu Rev Phytopathol 32:201-234

Bentes JLS, Barreto RW (2004) Taxonomic reevaluation of Colletotrichum guaranicola Albuq. causal agent of guarana anthracnose. Acta Amaz 34:129-131

Bentes JLS, Costa Neto PQ (2011) Variabilidade genética de Colletotrichum guaranicola usando marcadores AFLP. Acta Amaz 41:251-256

Bentes JLS, Matsuoka K (2002) Histologia da interação Colletotrichum guaranicola e Paullinia cupana var. sorbilis em clones resistente e suscetível. Fitopatol Bras 27:71-77

Blum H, Beier H, Gross H (1987) Improved silver staining of plant proteins RNA and DNA in polyacrylamide gels. Electrophoresis 8:93-99. doi:10.1002/ elps. 1150080203

Bodenhause N, Horton MW, Bergelson J (2013) Bacterial communities associated with the leaves and the roots of Arabidopsis thaliana. PLoS One 8(2):e56329. doi:10.1371/journal.pone.0056329

Bulgarelli D, Schlaeppi K, Spaepen S, Van Themaat EVL, Schulze-Lefert P (2013) Structure and functions of the bacterial microbiota of plants. Annu Rev Pant Biol 64:807-838. doi:10.1146/annurev-arplant-050312-120106

Bulgari D, Casati P, Crepaldi P, Daffonchio D, Quaglino F, Brusetti L (2011) Restructuring of endophytic bacterial communities in grapevine yellowsdiseased and recovered Vitis vinifera L. plants. Appl Environ Microbiol 77:5018-5022. doi:10.1128/AEM.00051-11 
Chelius MK, Triplett EW (2001) The diversity of archaea and bacteria in association with the roots of Ze mays. Microb Ecol 41:52-263

Choudhary D, Johri B (2009) Interactions of Bacillus spp. and plants-with special reference to induced system resistance (ISR). Microbiol Res 164:493-513. doi:10.1016/j.micres.2008.08.007

Clarke KR, Green RH (1988) Statistical design and analysis for a biological effects study. Mar Ecol Prog Ser 46:213-226

Costa LEO, Queiroz MV, Borges AC, Moraes CA, Araújo EF (2012) Isolation and characterization of endophytic bacteria isolated from the leaves of the common bean (Phaseolus vulgaris). Braz J Microbiol. doi:10.1590/ S1517-838220120004000041

Ewing B, Hillier L, Wendl MC, Green P (1998) Base-calling of automated sequencer traces using phred. I. Accuracy assessment. Genome Res 8:175-185. doi:10.1101/gr.8.3.175

Gagne-Bourgue F, Aliferis KA, Seguin P, Rani M, Samson R, Jabaji S (2013) Isolation and characterization of indigenous endophytic bacteria associated with leaves of switchgrass (Panicum virgatum L.) cultivars. J Appl Microbiol 114:836-853. doi:10.1111/jam.12088

Gao FK, Dai CC, Liu XZ (2010) Mechanisms of fungal endophytes in plant protection against pathogens. Afr J Microbiol Res 4:1346-1351

Gottel NR, Castro HF, Kerley M, Yang Z, Pelletier DA, Podar M et al (2011) Distinct microbial communities within the endosphere and rhizosphere of Populus deltoids roots across contrasting soil types. Appl Environ Microbiol 77:5934-5944. doi:10.1128/AEM.05255-11

Hallmann J, Quadt-Hallmann A, Rodrígues-Kábana R, Kloepper JW (1998) Interactions between Meloidogyne incognita and endophytic bacteria in cotton and cucumber. Soil Biol Biochem 30:925-937

Heuer H, Smalla K (1997) Application of denaturing gradient gel electrophoresis (DGGE) and temperature gradient gel electrophoresis (TGGE) for studying soil microbial communities. In: van Elsas JD, Trevors JT, Wellington EMH (eds) Modern soil microbiology. Marcel Dekker, Inc., New York, pp 353-373

Hoffman MT, Arnold AE (2010) Diverse bacteria inhabit living hyphae of phylogenetically diverse fungal endophytes. Appl Environ Microbiol 76:4063-4075. doi:10.1128/AEM.02928-09

Instituto Brasileiro de Geografia e Estatística-IBGE (2013) Levantamento sistemático da produção agrícola: pesquisa mensal de previsão e acompanhamento das safras agrícolas no ano civil. Rio de Janeiro, pp 83. ISSN 0103-443X

Jackson CR, Randolph KC, Osborn SL, Tyler HL (2013) Culture dependent and independent analysis of bacterial communities associated with commercial salad leaf vegetables. BMC Microbiol 13:274. doi:10.1186/1471-2180-13-274

Ji SH, Guranani MA, Chun SC (2014) Isolation and characterization of plant growth promoting endophytic bacteria from Korean rice cultivars. Microbiol Res 169:83-98. doi:10.1016/j.micres.2013.06.003

Jin H, Yang XY, Yan ZQ, Liu Q, Li XZ, Chen JX et al (2013) Characterization of rhizosphere and endophytic bacterial communities from leaves, stems and roots of medicinal Stellera chamaejasme L. Syst Appl Microbiol 5:376-385. doi:10.1016/j.syapm.2014.05.001

Jukes TH, Cantor CR (1969) Evolution of protein molecules. In: Munro HN (ed) Mammalian protein metabolism. Academic Press, New York, pp 21-132

Kim M, Singh D, Lai-Hoe A, Go R, Rahim RA, Ainuddin AN, Chun J, Adams J (2012) Distinctive phyllosphere bacterial communities in tropical trees. Microb Ecol 63:674-681. doi:10.1007/s00248-011-9953-1

Krid S, Rhouma A, Mogou I, Quesada JM, Nesme X, Gargouri A (2010) Pseudomonas savastonoi endophytic bacteria in olive tree knots and antagonistic potential of strains of Pseudomonas fluorescens and Bacillus subtilis. J Plant Pathol 92:335-341

Kuri CMB (2008) The guaraná industry in Brazil. Int Bus Econ Res J 7:87-98

Lacava PT, Araújo WL, Macon J, Maccheroni WJ, Azevedo JL (2004) Interaction between endophytic bacteria from citrus plants and the phytopathogenic bacteria Xylella fastidiosa, causal agent of citrus-variegated chlorosis. Lett Appl Microbiol 39:55-59. doi:10.1111/j.1472-765X.2004.01543.x

Lacava PT, Araújo WL, Azevedo JL, Hartung JS (2006) Rapid, specific and quantitative assays for the detection of the endophytic bacterium Methylobacterium mesophilicum in plants. J Microbiol Meth 65:535-541. doi:10.1016/j.mimet.2005.09.015

Lian J, Wang Z, Zhou S (2008) Response of endophytic bacterial communities in banana tissue culture plantlets to Fusarium wilt pathogen infection. J Gen Appl Microbiol 54:83-92. doi:10.2323/jgam.54.83
López-Velasco G, Welbaum GE, Falkinham JO, Ponder MA (2011) Phyllosphere bacterial community structure of spinach (Spinacia oleracea) as affected by cultivar and environmental conditions at time of harvest. Diversity 3:721-738. doi:10.3390/d3040721

Ma B, Xiaofei Lv, Warren A, Gong J (2013) Shifts in diversity and community structure of endophytic bacteria and archaea across root, stem and leaf tissues in the common reed, Phragmites australis, along a salinity gradient in a marine tidal wetland of northern China. Ant van Leeuw 104:759-768. doi:10.1007/s10482-013-9984-3

Mejía LC, Rojas El, Maynard Z, Bael SV, Arnold AE, Hebbar P et al (2008) Endophytic fungi as biocontrol agents of Theobroma cacao pathogens. Biol Control 46:4-14. doi:10.1016/j.biocontrol.2008.01.012

Melnick RL, Suárez C, Bailey BA, Backman PA (2011) Isolation of endophytic endospore-forming bacteria from Treobroma cacao as potential biological control agents of cacao diseases. Biol Control 57:236-245. doi:10.1016/j.biocontrol.2011.03.005

Muyzer G, Smalla K (1998) Application of denaturing gradient gel electrophoresis (DGGE) and temperature gradient gel electrophoresis (TGGE) in microbial ecology. Ant van Leeuw 73:127-141

Nováková E, Hypsa V, Moran NA (2009) Arsenophonus, an emerging clade of intracellular symbionts with a broad host distribution. BMC Microbiol 9:143. doi:10.1186/1471-2180-9-143

Paz LCP, Santin RCM, Guimarães AM, Rosa OPP, Dias ACF, Quecine MC et al (2012) Eucalyptus growth promotion by endophytic Bacillus spp. Genet Mol Res 11:3711-3720

Peñuelas J, Rico L, Ogaya R, Jump AS, Terradas J (2011) Summer season and long-term drought increase the richness of bacteria and fungi in the foliar phyllosphere of Quercrus ilex in a mixed Mediterranean forest. Plant Biol 14:565-575. doi:10.1111/j.1438-8677.2011.00532.x

Perkins SD, Mayfield J, Fraser V, Angenent LT (2009) Potentially pathogenic bacteria in shower water and air of a stem cell transplant unit. Appl Environ Microbiol 5:5363-5372. doi:10.1128/AEM.00658-09

Rajendran L, Ramanathan A, Durairaj C, Samiyappan R (2011) Endophytic Bacillus subtilis enriched with chitin offer induced systemic resistance in cotton against aphid infestation. Arch Phytopathol Plant Prot 44:1375-1389. doi:10.1080/03235408.2010.499719

Rasche F, Trondl R, Naglreiter C, Reichenauer TG, Sessitsch A (2006) Chilling and cultivar type affect the diversity of bacterial endophytes colonizing sweet pepper (Capsicum anuum L.). Can J Microbiol 52:1036-1045. doi:10.1139/w06-059

Rastogi G, Sbodio A, Tech JJ, Suslow TV, Coaker GL, Leveau JHJ (2012) Leaf microbiota in an agroecosystem spatio temporal variation in bacterial community composition on field-grown lettuce. ISME J 6:1812-1822. doi:10.1038/ismej.2012.32

Reiter B, Pfeifer U, schwab H, Sessitsch A (2002) Response of endophytic bacteria communities in potato plants to infection with Erwinia carotovora subsp. atroseptica. Appl Environ Microbiol 68:2261-2268. doi:10.1128/ AEM.68.5.2261-2268

Romero FM, Marina M, Pieckenstain FL (2014) The communities of tomato (Solanum lycopersicum L.) leaf endophytic bacteria, analyzed by $16 \mathrm{~S}$ ribosomal RNA gene pyrosequencing. FEMS Microbiol Lett 351:187-194. doi:10.1111/1574-6968.12377

Rosenblueth M, Martínez-Romero E (2006) Bacterial endophytes and their interactions with hosts. Mol Plant Microbe Interact 19:827-837. doi:10.1094/MPMI-19-0827

Sagaram US, DeAngeli KM, Trivedi P, Andersen G, Lu SE, Wang N (2009) Bacterial diversity analysis of Huanglongbing pathogen-infected Citrus, using phylochip arrays and 16 rRNA gene clone library sequencing. Appl Environ Microbiol 75:1566-1574. doi:10.1128/AEM.02404-08

Santos P, Pinhal I, Rainey FA, Empadinhas N, Costa J, Fields B et al (2003) Gamma-Proteobacteria Aquicella lusitana gen. nov., sp. nov., and Aquicella siphonis sp. nov. infect protozoa and require active charcoal for growth in laboratory media. Appl Environ Microbiol 69:6533-6540. doi:10.1128/ AEM.69.11.6533-6540

Schloss PD (2009) A high-throughput DNA sequence aligner for microbial ecology studies. PLoS One 4:e8230. doi:10.1371/journal.pone.0008230

Schloss PD, Larget BR, Handelsman J (2004) Integration of microbial ecology and statistics: a test to compare gene libraries. Appl Environ Microbiol 70:5485-5492. doi:10.1128/AEM.70.9.5485-5492

Sturz AV, Christie BR (2003) Beneficial microbial allelopathies in the root zone: the management of soil quality and plant disease with rhizobacteria. Soil Till Res 72:107-123. doi:10.1016/S0167-1987(03)00082-5 
Tamura K, Dudley J, Kumar NM (2007) MEGA4: molecular evolutionary genetics analysis (MEGA) software version 4.0. Mol Biol Evol 24:1596-1599. doi:10.1093/molbev/msm092

Tavares AM, Atroch AL, Nascimento Filho FJ, Pereira JCR, Araújo JCA, Moraes LAC et al (2005) Cultura do guaranazeiro no Amazonas, 4th edn. Embrapa Amazônia Ocidental, Manaus, p 40p

Trindade DR, Poltronieri LS (1997) Doenças do guaraná (Paullinia cupana Ducke). In: Kimati H, Amorim L, Bergamin Filho A, Camargo LEA, Resende JAM (eds) Manual de fitopatologia, vol 2. Agronômica Ceres, São Paulo, pp 459-462

Trivedi P, Duan Y, Wang N (2010) Huanglonbing, a systemic disease, restructures the bacterial community associated with Citrus roots. Appl Environ Microbiol 76:3427-3436. doi:10.1128/AEM.02901-09

Ulrich K, Ulrich A, Ewald D (2008) Diversity of endophytic bacterial communities in poplar grown under field conditions. FEMS Microbio Ecol 63:169-180. doi:10.1111/j.1574-6941-2007.00419.x
Videira SS, Silva MCP, Galisa OS, Dias ACF, Nissinen R, Divan VLB et al (2013) Culture-independent molecular approaches reveal a mostly unknown high diversity of active nitrogen-fixing bacteria associated with Pennisetum purpureum - a bioenergy crop. Plant Soil 373:737-754. doi:10.1007/ s11104-013-1828-4

Xiong XQ, Liao HD, Ma JS, Liu XM, Zhang LY, Shi XW et al (2013) Isolation of a rice endophytic bacterium, Pantoea sp. SD-1, with ligninolytic activity and chacacterization of its rice straw degradation ability. Lett Appl Microbiol 58:123-129. doi:10.1111/lam.12163

Yashiro E, Spear RN, McManus PS (2011) Culture-dependent and cultureindependent assessment of bacteria in the apple phyllosphere. J Appl Microbiol 110:1284-1296. doi:10.1111/j.1365-2672.2011.04975.x

\section{Submit your manuscript to a SpringerOpen ${ }^{\odot}$ journal and benefit from:}

- Convenient online submission

- Rigorous peer review

- Immediate publication on acceptance

- Open access: articles freely available online

- High visibility within the field

- Retaining the copyright to your article

Submit your next manuscript at $>$ springeropen.com 